\title{
Apolipoprotein A5 in Health and Disease
}

\section{J. A. HUBÁČEK ${ }^{1,2,3,4}$, V. ADÁMKOVÁ ${ }^{2,3}$, M. VRABLÍK ${ }^{4}$, M. KADLECOVÁ ${ }^{1,5}$, J. ZICHA $^{1,5}$, J. KUNEŠ $\check{S}^{1,5}$, J. PIŤHA ${ }^{1,5}$, P. SUCHÁNEK ${ }^{1,2}$, R. POLEDNE ${ }^{1,2}$}

${ }^{1}$ Center for Cardiovascular Research, Prague, ${ }^{2}$ Institute for Clinical and Experimental Medicine, Prague, ${ }^{3}$ South Bohemia University, Faculty for Public Health and Social Studies, České Budějovice, ${ }^{4}$ Third Department of Medicine, First Faculty of Medicine of Charles University and General University Hospital in Prague, ${ }^{5}$ Institute of Physiology AS CR, Prague, Czech Republic

Received April 27, 2009

Accepted October 30, 2009

\section{Summary}

High plasma levels of triglycerides (TG) are an independent risk factor in the development of cardiovascular disease, with about $50 \%$ of the final levels being determined genetically. Apolipoprotein A5 (APOA5) is the last discovered member of the apolipoprotein $A P O A 1 / C 3 / A 4$ gene cluster, found by comparative sequencing analysis. The importance of $A P O A 5$ gene for determination of plasma triglyceride levels has been suggested after development of transgenic and knock-out mice (transgenic mice displayed significantly reduced TG, whereas knock-out mice had high TG). In Czech population, alleles C-1131 and Trp19 are associated with elevated levels of plasma TG and higher risk of myocardial infarction development. These alleles also play some role in nutrigenetics and actigenetics of lifestyle interventions leading to the plasma cholesterol changes as well as in the pharmacogenetics of statin treatment. On the contrary, APOA5 mutations detected in Czech population did not show strict effect on plasma TG levels. Val153 $\rightarrow$ Met variant exhibit the sexspecific effect of HDL-cholesterol levels. The suggested roles of APOA5 variants in determination of the plasma remnant particles, plasma concentrations of C-reactive protein or some anthropometrical parameters were excluded.

\section{Key words}

Apolipoprotein A5 • Triglycerides • Polymorphism • Myocardial infarction

\section{Corresponding author}

J. A. Hubáček, IKEM-CEM-LMG, Vídeňská 1958/9, 14021 Prague

4, Czech Republic. Fax: +420 241721 574. E-mail: jahb@ikem.cz

\section{Introduction}

Cardiovascular disease is the most common cause of death in industrialized countries, with high plasma triglyceride (TG) levels being suggested to be independent risk factor (Austin et al. 1987, Forester 2001). It is known, that plasma levels of TG are influenced by dietary composition, smoking, body weight and genetic factors. Similarly to the other risk factors, it is estimated that the contribution of genetic and environmental factors on plasma levels of TG is roughly the same.

The genetic predisposition to a high level of plasma TG levels has been intensively analyzed in last 15 years. Dozens of polymorphisms in different genes that could have some effect on plasma TG levels have been analyzed so far (for example Gehrisch 1999, Cohen et al. 1999, Talmud and Humphries 2001).

The most promising results are connected with variants within the apolipoproteins (APO) $A P O A 1 / A P O C 3 / A P O A 4$ gene cluster. Especially the $A P O C 3$ SstI (rs5128) polymorphism (Talmud and Humphries 2001) is known as the important genetic determinant of plasma TG levels. However the described results are not consistent (Buzza et al. 2001, Hubáček et al. 2001, Russo et al. 2001). Additionally, this

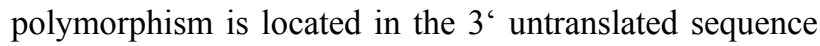
of the $A P O C 3$ gene - thus the mechanism of its influence is not clear. One of the possibilities is that this variant is in linkage disequilibrium with another functional variant in the same region. 
This lead to intensive investigation of the DNA sequence around the APOA1/APOC3/APOA4 gene cluster. The available mice and human sequences around this locus were completed by sequencing and compared. About 200000 bp of mouse and human sequences were analyzed and this comparison leads to the identification of evolutionary highly conserved sequence that contained a putative lipid-binding apolipoprotein gene. Matching this sequence with mouse expressed sequences suggested the presence of the new apolipoprotein - and apolipoprotein $A 5$ gene (APOA5) in APOA1/APOC3/APOA4 gene cluster was defined (Pennacchio et al. 2001).

Construction of transgenic and knock-out mice definitely assessed the importance of this gene for plasma TG determination. The transgenic mice exhibited diminished, and the knock out mice elevated levels of plasma TG, while the plasma cholesterol levels were not influenced significantly (Pennacchio et al. 2001).

\section{Description and function of apolipoprotein A5 gene}

The whole sequence of the human $A P O A 5$ gene was analyzed in details. The human $A P O A 5$ gene consists of 4 exons and codes 369 aminoacid protein, which is expressed almost exclusively in the liver (Pennacchio et al. 2001).

ApoA5 is located on $\mathrm{TG}$ rich particles (chylomicrones and very low density lipoproteins VLDL) and high density lipoprotein (HDL) particles. In comparison to other apolipoproteins, the plasma concentration of apoA5 is low in human - about $100 \mu \mathrm{g} / 1$ (O'Brien et al. 2005). Others detected that apoA5 binds to and enhances the activity of lipoprotein lipase (LPL) (Fruchart-Najib et al. 2004, Schaap et al. 2004). This lead in mice expressing human apoA5 to reduction of TG levels in VLDL particles. Additionally, the treatment with apoA5 lead in mice to a reduction of VLDL-TG production rate, but the concentration of the VLDL particles was the same as in normal mice (Fruchart-Najib et al. 2004, Schaap et al. 2004). This result was confirmed recently by Priore-Oliva et al. (2005) on patients with $A P O A 5$ mutations resulting in premature stop codons (Gln145 $\rightarrow$ Stop and Gln $139 \rightarrow$ Stop). The mutation Gln145 $\rightarrow$ Stop was present in homozygous form and plasma of this patient was found to activate LPL in vitro less efficiently than plasma from control subjects. These results confirmed that apoA5 plays a role in activation of LPL. Very recently, Dorfmeister et al. (2008) have demonstrated that recombinant APOA5 interacts with high affinity with the LDL receptor family members. This result suggests that plasma concentration of APOA5 could not be necessarily a reliable marker of its function and will not be of major importance.

Inside the APOA5 gene more than 15 different variants have been detected (Pennacchio et al. 2002, summarized by Hubáček 2004, 2005), the majority of them were also detected in Czech population (Table 1).

Table 1. Summary of the apolipoprotein A5 gene variants analyzed in more details in the Czech population. A-3>C variant is in almost complete linkage disequilibrium with $\mathrm{T}-1131>\mathrm{C}$ variant, thus, was not associated with details separately. $\mathrm{N}$ refers to the position on the figure.

\begin{tabular}{|c|c|c|c|}
\hline $\mathbf{N}$ & $A P O A 5$ variant & $\begin{array}{l}\text { Population } \\
\text { frequencies } \\
\text { of variant } \\
\text { allele }\end{array}$ & $\begin{array}{c}\text { Association } \\
\text { with TG } \\
\text { levels }\end{array}$ \\
\hline 1 & $T-1131>C$ & $\sim 8.5 \%$ & +++ \\
\hline 2 & $A-3>C$ & $\sim 8.5 \%$ & +++ \\
\hline 3 & $\operatorname{Ser} 19>\operatorname{Tr} p(C 56>G)$ & $\sim 7.2 \%$ & +++ \\
\hline 4 & $\operatorname{Val153}>\operatorname{Met}(G 457>A)$ & $\sim 3.8 \%$ & - \\
\hline 5 & Gly185>Cys $(G 553>C)$ & Not detected & \\
\hline 6 & Ala315>Val $(C 944>T)$ & $<1 \%$ & $?$ \\
\hline 7 & His321>Leu $(A 962>T)$ & $<1 \%$ & $?$ \\
\hline & $\begin{array}{c}\text { ATG } \\
\downarrow\end{array}$ & & $\begin{array}{c}\text { TGA } \\
\downarrow\end{array}$ \\
\hline$\uparrow$ & $\begin{array}{ll}T & T \\
2 & 3\end{array}$ & & $\uparrow_{67}$ \\
\hline
\end{tabular}

ATG - start codon, TGA, stop codon.

In collaborations with other groups we have screened the entire gene sequence for DNA variants in more than one hundred individuals and if the detected APOA5 variants (both polymorphisms and mutations; mostly mismatched variants and variants located in promoter of the gene) are associated with or have effect on

1) plasma lipid levels (triglycerides, remnant particles, LDL cholesterol, HDL cholesterol, non-HDL cholesterol) in different groups of individuals of both genders

2) development of extreme hypertriglyceridemia 
3) development of myocardial infarction

4) response to environmental changes - live style and pharmacological interventions in different population cohort, i.e. nutrigenetics, actigenetics and pharmacogenetics.

5) confirmatory analysis of the relationships between APOA5 variants and different biochemical/ anthropometrical parameters reported by other research groups.

Additionally, we have analyzed apoA5 gene organisation, sequence and expression in Prague hypertriglyceridemic rats.

\section{Association between $A P O A 5$ and plasma lipid levels in general population}

When 501 individuals (European-Americans, healthy non-smokers, without lipid lowering medications) were originally genotyped, an association has been found between $\mathrm{T}-1131 \rightarrow \mathrm{C}$ (rs662799) polymorphism as well as between Ser19 $\rightarrow \operatorname{Trp}(\mathrm{C} 56 \rightarrow \mathrm{G}$, rs3135506) variant and plasma levels of TG on random, high-fat as well as on low-fat diet (Pennacchio et al. 2001, 2002). In both cases, individuals with at least one less common allele had significantly higher TG levels than the others.

We have confirmed the original finding on representatively selected ethnically homogenous group of Czechs (1191 males and 1368 females, mean age $48.0 \pm 10.7$ years), where plasma TG levels were analyzed twice independently in two different examinations (years 1997/8 and 2000/1) (Hubáček et al. 2003, 2004a).

$\mathrm{T}-1131 \rightarrow \mathrm{C}$ variation affects plasma TGs showing a higher level in C-1131 carriers than in T/T1131 homozygotes. This association has been observed in both years (only the year 2001 is shown) in both males $(2.40 \pm 1.63 \mathrm{mmol} / \mathrm{l}$ vs. $2.06 \pm 1.66 \mathrm{mmol} / \mathrm{l})(\mathrm{p}<0.001)$ and females $(1.57 \pm 0.85 \mathrm{mmol} / \mathrm{l}$ vs. $1.43 \pm 0.85 \mathrm{mmol} / \mathrm{l})$ $(\mathrm{p}<0.001)$. The same variant affects the plasma non-HDL cholesterol showing significantly higher levels in C-1131 carriers than in T/T-1131 homozygotes. This association has been observed in both males $(4.61 \pm 1.09 \mathrm{mmol} / \mathrm{l} \mathrm{vs}$. $4.47 \pm 1.07 \mathrm{mmol} / \mathrm{l}, \quad \mathrm{p}<0.01)$ and females $(4.46 \pm 1.22$ $\mathrm{mmol} / \mathrm{l}$ vs. $4.24 \pm 1.17 \mathrm{mmol} / \mathrm{l}, \mathrm{p}<0.01)$. Interestingly, if LDL cholesterol (obtained by Friedewald formula) or HDL cholesterol were analyzed, no significant association was detected (Hubáček et al. 2008a). This may be explained by the fact, that the small but significant part of cholesterol is located in VLDL particles.

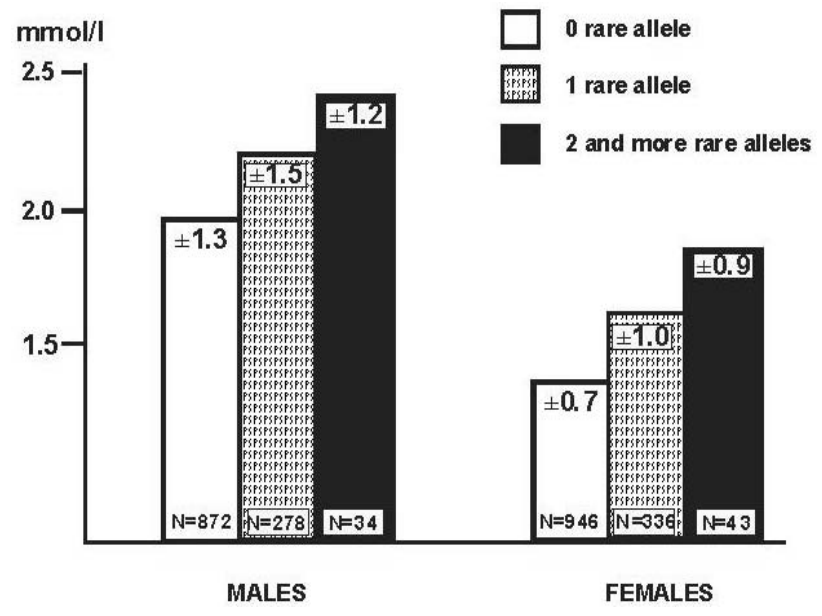

Fig. 1. Schematic summary of the additive effect of two common APOA5 variants (T-1131 $\rightarrow \mathrm{C}$ and Ser $19 \rightarrow$ Trp) on plasma triglycerides. Each less common individual allele (C-1131 and Trp19) adds $\sim 10 \%$ to the total value.

Plasma TG were also influenced by the Ser19 $\rightarrow$ Trp APOA5 genotypes. In both males $(2.40 \pm 1.97 \mathrm{mmol} / \mathrm{l}$ vs. $2.07 \pm 1.60 \mathrm{mmol} / \mathrm{l})$ and females $(1.65 \pm 1.02 \mathrm{mmol} / \mathrm{l} \mathrm{vs}$. $1.43 \pm 0.82 \mathrm{mmol} / \mathrm{l})$, the Trp19 carriers have triglycerides significantly (both $\mathrm{p}<0.001$ ) higher compared to the Ser19 homozygotes. All these results (Fig. 1) are consistent with the associations detected in all other Caucasian populations, where all studies find significant associations between TG concentrations and APOA5 polymorphisms, despite the fact, that the strengths of the associations vary between studies (Hubáček 2005, Tai and Ordovas 2008).

Interestingly, the third common APOA5 variant (Val153 $\rightarrow$ Met, G457 $\rightarrow$ A, rs3135507) has no effect on plasma $\mathrm{TG}$ in the same population. Nevertheless in females (but not in males) we have detected (Hubáček et al. 2005a) an association between this variant and plasma HDL cholesterol levels showing a higher level in Val/Val homozygotes than in Met carriers $(1.52 \pm 0.37 \mathrm{mmol} / 1$ compared to $1.39 \pm 0.35 \mathrm{mmol} / \mathrm{l}, \mathrm{p}<0.01)$.

Remnant lipoproteins (RLP) are product of catabolized TG-rich particles. Elevated levels of RLP are associated with atherosclerosis and they are a predictor of coronary events in patients with coronary artery disease, mainly in women (McNamara et al. 2001).

We have evaluated the influence of APOA5 polymorphisms $(\mathrm{T}-1131 \rightarrow \mathrm{C}$, Ser19 $\rightarrow$ Trp and Val153 $\rightarrow$ Met) on plasma levels of RLP-cholesterol and RLPTG in 285 unrelated representative selected individuals (131 men and 154 women) aged 33-72 years. RLPcholesterol and RLP-TG levels were not significantly 
influenced by the APOA5 variants either in whole population or in males and females, if analyzed separately. We conclude that variations $\mathrm{T}-1131 \rightarrow \mathrm{C}$, Ser19 $\rightarrow$ Trp and Val153 $\rightarrow$ Met in the APOA5 gene have no effect on plasma levels of remnant particles (Hubáček et al. 2004b).

In 369 patients with diabetes mellitus type 1 and 2 (202 males and 167 females), we have analyzed an association between $A P O A 5$ variants T-1131 $\rightarrow$ C, Ser19 $\rightarrow$ Trp and Val153 $\rightarrow$ Met and plasma lipid levels. In contrast to healthy population, $\mathrm{T}-1131 \rightarrow \mathrm{C}$ was associated not only with plasma levels of triglycerides, but also with plasma levels of LDL-cholesterol (in these individuals, the LDL-cholesterol was not calculated, but directly measured in plasma) both in males and females. T-1131T homozygotes have significantly elevated plasma levels of LDL cholesterol $(3.31 \pm 0.07 \mathrm{mmol} / \mathrm{l}$ vs. $2.98 \pm 0.14 \mathrm{mmol} / 1$ in females and $3.21 \pm 0.06 \mathrm{mmol} / 1 \mathrm{vs}$. $2.95 \pm 0.16 \mathrm{mmol} / 1$ in males, both $\mathrm{p}<0.05)$ and significantly lower levels of TG $(1.78 \pm 0.10 \mathrm{mmol} / \mathrm{l} \mathrm{vs}$. $2.31 \pm 0.14 \mathrm{mmol} / 1$ in females and $2.04 \pm 0.26 \mathrm{mmol} / \mathrm{l}$ vs. $3.03 \pm 0.73 \mathrm{mmol} / \mathrm{l}$ in females, both $\mathrm{p}<0.05)$ than carriers of the allele C-1131 (Hubáček, unpublished results).

\section{Association between $A P O A 5$ variants and extreme plasma triglyceride levels}

As the common variants within the APOA5 gene are associated with plasma TG levels, we have also analyzed them in the individuals with extremely high levels (more than $10 \mathrm{mmol} / \mathrm{l}$; mean $20.4 \pm 12.8 \mathrm{mmol} / \mathrm{l}$; $\mathrm{n}=83$ ). Further we have sequenced the APOA5 gene region in these patients in order to detect some new APOA5 variants, which could be responsible for the extreme TG levels.

As expected, the frequencies of the carriers of the less common alleles C-1131 and Trp19 were more than twice higher (both $\mathrm{p}<0.0001$ ) in hypertriglyceridemic patients $(32.5 \%$ and $30.1 \%$ respectively) than in control population (15.4\% and $14.1 \%$ respectively) (Hořínek et al. 2003, Vrablík et al. 2003).

No association between the Val153 $\rightarrow$ Met variant and extreme plasma levels of TG was found in the same group of patients (the frequencies of Met153 carriers were $6.5 \%$ in controls and $9.6 \%$ in patients). This implicated that Val153 $\rightarrow$ Met polymorphism in the APOA5 gene does not represent an important risk factor for developing extreme levels of plasma TG (Hubáček et al. 2004c).
Additional sequencing of these individuals reveals the presence of the two rare APOA5 mutations. Firstly, three carriers of the Ala315 $\rightarrow$ Val $($ C944 $\rightarrow$ T) variant have been detected within hypertriglyceridemic patients. However, in 3302 representatively selected healthy individuals we have found another 22 carriers of the Val315 allele, 19 out of them having normal triglyceride levels and only three elevated triglyceride levels. Therefore, we conclude that this variant itself does not play an important role in genetic determination of hypertriglyceridemia (Hubáček et al. 2008b). It may interact with other genetic variants to cause hypertriglyceridemia. Secondly, one hypertriglyceridemic individual with His321 $\rightarrow$ Leu $(\mathrm{A} 962 \rightarrow \mathrm{T})$ mutation (the variant was not found in 282 controls) was detected (Dorfmeister et al. 2008), but detailed analysis did not reveal the major importance of this change for $\mathrm{TG}$ metabolism.

Independently, the APOA5 variant Cys185 $\rightarrow$ Gly has been detected in Chinese population (Kao et al. 2003). We did not detect carriers of the Gly185 allele among 83 individuals with high plasma TG levels and 420 healthy individuals. We suppose that this variant is probably not present in Caucasian populations at all or the frequency is too low to have some detectable impact on plasma TG levels (Hubáček et al. 2004c).

\section{Association between $A P O A 5$ variants and myocardial infarction development}

All together, we have analyzed the genotype frequencies of the three common $A P O A 5$ polymorphisms in male patients under 65 years of age who survived theirs first myocardial infarction (MI) and compared them with the healthy control male population.

In a group of patients with MI $(n=435)$, the frequency of the rare homozygotes for at least one APOA5 variant (C/C-1131 and/or Trp/Trp19) was significantly $(7.4 \%$ vs. $2.0 \%, \mathrm{p}<0.00001)$ higher than in the population sample $(\mathrm{n}=1191)$ (Hubáček et al. 2003, 2004a). In contrast, the frequency of the Met153 carriers was not significantly different between these two groups (6.5\% vs. $6.4 \%$ ) (Hubáček et al. 2005a).

\section{Association between $A P O A 5$ variants and responses to interventions - nutrigenetics, actigenetics and pharmacogenetics}

The possible interactions between APOA5 
variants and environmental factors were analyzed in three studies with different design.

We have evaluated the influence of common variations in the APOA5 gene on plasma lipid levels in 117 males for whom dietary composition markedly changed and total cholesterol decreased (from $6.21 \pm 1.31 \mathrm{mmol} / \mathrm{l}$ in 1988 to $5.43 \pm 1.06 \mathrm{mmol} / \mathrm{l}$ in 1996 ) over an 8-year follow-up study. APOA5 T-1131 $\rightarrow \mathrm{C}$ and Val153 $\rightarrow$ Met variants did not influence the change in these measures over time. In contrast the Ser19 $\rightarrow$ Trp polymorphism was strongly associated with a decrease in plasma total cholesterol over the 8year time period. In Ser/Ser19 homozygotes the plasma cholesterol was relatively stable over the years $(6.1 \pm 1.2$ $\mathrm{mmol} / \mathrm{l}$ in 1988 and $5.6 \pm 1.0 \mathrm{mmol} / 1$ in $1996,-8 \%$ ). In the Trp19 carriers the decrease of the plasma cholesterol was more than $25 \%(6.5 \pm 1.6 \mathrm{mmol} / \mathrm{l}$ in 1988 and $5.1 \pm 1.0 \mathrm{mmol} / \mathrm{l}$ in 1996$)(\mathrm{p}<0.005)$. Changes in other analyzed lipid parameters (HDL-cholesterol, LDLcholesterol, triglycerides) have not been associated with other APOA5 variants (Hubáček et al. 2006, 2007).

Furthermore, 98 unrelated overweight and obese non-diabetic Czech females (BMI over $27.5 \mathrm{~kg} / \mathrm{m}^{2}$ ) whose underwent 9 weeks of lifestyle modification program consisting of a reduction of energy intake and the aerobic exercise were examined. No significant association between BMI decrease and APOA5 variants was found, but T-1131T carriers have significantly higher body weight both before and after intervention $(\mathrm{p}<0.05$ for BMI). Furthermore, plasma TG levels decreased in Ser19Ser homozygotes but increased in Trp19 carriers $(1.42 \pm 0.62 \mathrm{mmol} / 1$ vs. $1.28 \pm 0.48 \mathrm{mmol} / 1$ compared to $1.15 \pm 0.47 \mathrm{mmol} / 1$ vs. $1.41 \pm 0.80 \mathrm{mmol} / \mathrm{l}, \mathrm{p}<0.05)$. Similarly, in carriers of at least one less common APOA5 allele $(n=26)$, plasma LDL-cholesterol levels did not decreased as they did in $\mathrm{T}-1131 \mathrm{~T} / \mathrm{Ser} 19 \mathrm{Ser}$ carriers $(3.11 \pm 0.70 \mathrm{mmol} / 1$ vs. $3.27 \pm 0.81 \mathrm{mmol} / 1$ compared to $3.39 \pm 0.81 \mathrm{mmol} / 1$ vs. $3.16 \pm 0.86 \mathrm{mmol} / 1, \quad \mathrm{p}<0.05)$ (Suchánek et al. 2008).

Finally, we examined the putative association between APOA5 SNPs $(\mathrm{T}-1131 \rightarrow \mathrm{C}$, Ser19 $\rightarrow$ Trp and Val153 $\rightarrow$ Met) and efficacy of three months of low doses statin treatment in 188 adult Caucasians. Carriers of the APOA5 genotype TT-1131 benefited more from statin treatment in comparison to the $\mathrm{C}-1131$ allele carriers ( $\Delta$ LDL-C $-36.3 \pm 15.1 \%$ vs. $\Delta$ LDL-C $29.9 \pm 12.5 \% ; \mathrm{p}<0.005$, Mann-Whitney test) (Hubáček et al. 2009).

\section{Confirmatory analysis of the relationships between $A P O A 5$ variants and different biochemical/anthropometrical parameters reported by other research groups}

Associations between C-1131 allele and higher mother's height as well as with longer fetal birth length were suggested by Ward et al. (2003). The explanation for this association was the hypothesis that the elevated TG levels could lead to a better intrauterine nutrition of the fetus.

In 1305 females, aged between 28 and 67 years and having at least one child, we have analyzed a putative association between $\mathrm{T}-1131 \rightarrow \mathrm{C}$ APOA5 variant and body height. Mother's body height did not differ between $\mathrm{T} / \mathrm{T}$ homozygotes $(\mathrm{n}=1093,162.5 \pm 6.5 \mathrm{~cm})$ and $\mathrm{C}$ allele carriers $(\mathrm{n}=212,162.1 \pm 6.4 \mathrm{~cm})$. Thus we have failed to confirm, that mothers with APOA5 C-1131 allele are higher than T/T-1131 homozygotes (Hubáček et al. 2004d).

Association between the $\mathrm{T}-1131 \rightarrow \mathrm{C}$ APOA5 variant and plasma concentrations of $\mathrm{C}$-reactive protein in 158 young non-obese Korean males was described by Jang et al. (2004). Carriers of at least one allele C-1131 have higher plasma levels of C-reactive protein if compared to carriers of common $\mathrm{T}-1131 \mathrm{~T}$ genotype. In 1119 Caucasian males, (49.2 \pm 10.8 years), we have analyzed a putative association between common APOA5 variants and $\mathrm{C}$-reactive protein concentrations (after log transformation). C-reactive protein levels did not differ between T/T-1131 homozygotes ( $\mathrm{n}=946,0.33 \pm 0.24 \mathrm{mg} / \mathrm{l}$ ) and carriers of the $\mathrm{C}$ allele $(\mathrm{n}=173,0.33 \pm 0.23 \mathrm{mg} / \mathrm{l})$. Thus, in contrast to Korean males, in a large group of Caucasian males, $\mathrm{T}-1131 \rightarrow \mathrm{C}$ APOA5 variant had no effect on plasma concentrations of $\mathrm{C}$-reactive protein and also other APOA5 variants (Ser19 $\rightarrow$ Trp and Val153 $\rightarrow$ Met) did not influence plasma concentrations of C-reactive protein (Hubáček et al. 2005b).

In two studies, the interaction between common polymorphism (E2, E3 and E4) in $A P O E$ gene, APOA5 variant Ser19 $\rightarrow$ Trp and the occurrence of hypertriglyceridemia was analyzed.

Schaefer et al. (2004) found 7 APOE2/E2 out of 170 screened individuals with elevated TG levels (over $2.3 \mathrm{mmol} / \mathrm{l}$ ). Six of them also have Trp at position 19 in the APOA5 gene. Additionally, they have failed to detect this combination in healthy normolipidemic individuals.

In contrast, we did not find significant association between $A P O E 2 / E 2$ and presence of Trp19 
allele in the APOA5 gene in hypertriglyceridemic individuals (Hubáček et al. 2005c). However, in 111 patients with extreme TG levels $(>10 \mathrm{mmol} / \mathrm{l})$ more then $50 \%$ of the patients with the Trp19 allele also have APOE4 allele, in contrast to only $13 \%$ of such individuals in the whole population $(\mathrm{p}<0.001)$.

We have detected sex-specific interactions between the variants in $A P O A 5$ and $A P O E$ genes (Hubáček et al. 2008c) in the general population of 2500 representatively selected Caucasians (1168 males, 1332 females). In females (but not in males), an association between $A P O E$ polymorphism and total cholesterol (TC) was observed on the background of the common APOA5 haplotype (TT-1131/SerSer19) - APOE2 carriers have the lowest $(5.12 \pm 1.15 \mathrm{mmol} / \mathrm{l})$ and the APOE4 carriers the highest $(6.05 \pm 1.06 \mathrm{mmol} / \mathrm{l})$ levels of plasma TC $(\mathrm{p}<0.001)$. If at least one APOA5 C-1131 or Trp19 allele was present, $A P O E$ exhibited no significant effect on plasma TC. APOA5 did not affect plasma TG levels, if $A P O E 4$ allele was present. In the presence of $A P O E 2$ or $A P O E 3$, carriers of the APOA5 alleles C-1131 and/or Trp19 had higher TG levels $(1.64 \pm 1.05 \mathrm{mmol} / \mathrm{l})$ than others $(1.37 \pm 0.75 \mathrm{mmol} / \mathrm{l})(\mathrm{p}<0.01)$. In males, no similar associations were observed.

\section{ApoA5 gene organization, sequence and expression in Prague hereditary hypertri- glyceridemic rat}

Prague hereditary hypertriglyceridemic (HTG) rats are a useful model of human hypertriglyceridemia and other symptoms of metabolic syndrome (Vrána and Kazdová 1990). Thus, the variation of apoA5 gene and its expression were studied in this strain under normal conditions and after chronic fructose loading.

We have sequenced the whole apoA5 gene of these animals and Lewis and Whistar rats served as normotriglyceridemic controls. There were no differences in gene structure or sequences between these strains of rats. Similarly, the apoA5 expression after feeding the animals with fructose diet (which stimulates the development of hypertriglyceridemia) did not display significant differences between the strains (Kadlecová et al. 2006). Thus, in this model, apoA5 plays no important role in determination of plasma triglycerides.

\section{Conclusions}

Gene for apolipoprotein $A 5$ and effect of its variants on different lipid parameters under different conditions were analyzed in details on different individuals of the Czech origin. Careful analysis has confirmed that some of its variants have an important effect on plasma triglyceride concentration but that they could also influence the risk of myocardial infarction.

1) C-1131 and Trp19 alleles are associated with elevated levels of plasma $\mathrm{TG}$ in both males and females. Similarly to the healthy individuals, plasma TG levels (and LDL-cholesterol) are affected by APOA5 variant $\mathrm{T}-1131 \rightarrow \mathrm{C}$ also in patients with diabetes mellitus. Carriers of the Met153 allele have lower level of plasma HDL cholesterol, but this association is gender specific and valid just in the females. Concentration of remnant particles is not associated with $A P O A 5$ variants in Caucasians.

2) In hypertriglyceridemic patients, the frequencies of C-1131 and Trp19 alleles are significantly higher than in the control population. No association with extreme TG levels and Val153 $\rightarrow$ Met variant was detected. Cys185 allele was not detected in these patients and theirs controls ( $\sim 500$ individuals together) at all - thus the presence of this allele is most probably race specific. The exact role of other identified mutations (Ala315 $\rightarrow$ Val, and His321 $\rightarrow$ Leu) in determination of hypertriglyceridemia remains to be clarified.

3) Carriers of at least one genotype C-1131C or Trp19Trp have higher risk of myocardial infarction development.

4) Males carrying at least one allele Trp19 have better response to dietary changes in the population cohort than Ser19Ser homozygotes. Combined dietary/exercise intervention and statin treatment could also be more beneficial for some subgroups defined by APOA5 variants.

5) We failed to confirm the suggested associations of APOA5 variants with either height of mothers or with plasma levels of C-reactive protein in males.

6) Certain, but so far not completely understood interaction between development of hypertriglyceridemia and $A P O E$ and $A P O A 5$ genotypes is possible.

In conclusion, despite its low plasma concentration, APOA5 gene and its variants is so far the strongest determinant of plasma triglycerides in humans.

\section{Conflict of Interest}

There is no conflict of interest.

\section{Acknowledgements}

The summarized studies were predominantly supported 
by the project number 1M0510 (Ministry of Education, Youth and Sports of the Czech Republic). International collaborations were supported by project No. MEB 060808 (WTZ Ö-Cz). JAH is further supported by project
No. 00023001 (IKEM). MV is supported by project No. MSM 0021620807, VA by the project 8895-4 (IGA MZ CR), PS by the project No 9393-3 (IGA MZ CR).

\section{References}

AUSTIN MA, KING MC, BAWOL RD, HULLEY SB, FRIEDMAN GD: Risk factors for coronary heart disease in adult female twins. Genetic heritability and shared environmental influences. Am J Epidemiol 125: 308-318, 1987.

BUZZA M, FRIPP Y, MITCHELL RJ: Apolipoprotein AI and CIII gene polymorphisms and their association with lipid levels in Italian, Greek and Anglo-Irish populations of Australia. Ann Hum Biol 28: 481-490, 2001.

COHEN JC, VEGA GL, GRUNDY SM: Hepatic lipase: new insights from genetic and metabolic studies. Curr Opin Lipidol 10: 259-267, 1999.

DORFMEISTER B, ZENG WW, DICHLBERGER A, NILSSON SK, SCHAAP FG, HUBÁČEK JA, MERKEL M, COOPER JA, LOOKENE A, PUTT W, WHITTALL R, LEE PJ, LINS L, DELSAUX N, NIERMAN M, KUIVENHOVEN JA, KASTELEIN JJ, VRABLÍK M, OLIVECRONA G, SCHNEIDER WJ, HEEREN J, HUMPHRIES SE, TALMUD PJ: Effects of six APOA5 variants, identified in patients with severe hypertriglyceridemia, on in vitro lipoprotein lipase activity and receptor binding. Arterioscler Thromb Vasc Biol 28: 1866-1871, 2008.

FORESTER JS: Triglycerides: risk factor or fellow traveler? Curr Opin Cardiol 16: 261-264, 2001.

FRUCHART-NAJIB J, BAUGE E, NICULESCU LS, PHAM T, THOMAS B, ROMMENS C: Mechanism of triglyceride lowering in mice expressing human apolipoprotein A5. Biochem Biophys Res Commun 319: $397-$ 404, 2004.

GEHRISCH S: Common mutations of the lipoprotein lipase gene and their clinical significance. Curr Atheroscler Rep 1: 70-78, 1999.

HOŘÍNEK A, VRABLÍK M, ČEŠKA R, ADÁMKOVÁ V, POLEDNE R, HUBÁČEK JA: T-1131 $\rightarrow$ C polymorphism within the apolipoprotein AV gene in hypertriglyceridemic individuals. Atherosclerosis 167: 369-370, 2003.

HUBÁČEK JA: Apolipoprotein AV and triglyceridemia. (in Czech) Cas Lek Cesk 143: 799-803, 2004.

HUBÁČEK JA: Apolipoprotein A5 and triglyceridemia. Focus on the effects of the common variants. Clin Chem Lab Med 43: 897-902, 2005.

HUBÁČEK JA, WATERWORTH DM, POLEDNE R, POLEDNE R, PIŤHA J, ŠKODOVÁ Z, HUMPHRIES SE, TALMUD PJ: Genetic determination of plasma lipids and insulin in the Czech population. Clin Biochem 34: 113-118, 2001.

HUBÁČEK JA, ŠKODOVÁ Z, ADÁMKOVÁ V, VRABLÍK M, HOŘÍNEK A, LÁNSKÁ V, ČEŠKA R, POLEDNE $\mathrm{R}$ : $A P O A V$ polymorphisms (T-1131/C and Ser19/Trp) influence plasma triglyceride levels and risk of myocardial infarction. Exp Clin Cardiol 8: 151-154, 2003.

HUBÁČEK JA, ŠKODOVÁ Z, ADÁMKOVÁ V, LÁNSKÁ V, POLEDNE R: The influence of APOAV polymorphisms (T-1131 $>\mathrm{C}$ and $\mathrm{S} 19>\mathrm{W})$ on plasma triglyceride levels and risk of myocardial infarction. Clin Genet 65: 126-130, 2004a.

HUBÁČEK JA, KOVÁŘ J, ŠKODOVÁ Z, PIŤHA J, LÁNSKÁ V, POLEDNE R: Genetic analysis of APOAV polymorphisms (T-1131/C, Ser19/Trp and Val153/Met): no effect on plasma remnant particles concentrations. Clin Chim Acta 348: 171-175, 2004 b.

HUBÁČEK JA, ADÁMKOVÁ V, ČEŠKA R, POLEDNE R, HOŘÍNEK A, VRABLÍK M: New variants in the apolipoprotein AV gene in individuals with extreme triglyceride levels. Physiol Res 53: 225-228, 2004c.

HUBÁČEK JA, ŠKODOVÁ Z, ADÁMKOVÁ V, LÁNSKÁ V, BOBKOVÁ D, POLEDNE R: APOAV (T-1131>C) variant has no effect on mother's height in a large population study. Lipids Health Dis 3: 10, 2004d.

HUBÁČEK JA, ŠKODOVÁ Z, ADÁMKOVÁ V, LÁNSKÁ V, POLEDNE R: Sex-specific effect of APOAV variant (Val153>Met) on plasma levels of high-density lipoprotein cholesterol. Metabolism 54: 1632-1635, $2005 \mathrm{a}$. 
HUBÁČEK JA, ŠKODOVÁ Z, LÁNSKÁ V, STÁVEK P, ADÁMKOVÁ V, POLEDNE R: Apolipoprotein AV variants do not affect C-reactive protein levels in Caucasian males. Physiol Res 54: 687-689, 2005b.

HUBÁČEK JA, HOŘÍNEK A, ŠKODOVÁ Z, ADÁMKOVÁ V, ČEŠKA R, ZLATOHLÁVEK L, VRABLÍK M: Hypertriglyceridemia: interaction between APOE and APOAV variants. Clin Chem 51: 1311-1313, 2005c.

HUBÁČEK JA, ŠKODOVÁ Z, ADÁMKOVÁ V, LÁNSKÁ V, PIŤHA J: APOA5 variant Ser19Trp influences a decrease of the total cholesterol in a male 8 year cohort. Clin Biochem 39: 133-136, 2006.

HUBÁČEK JA, BOHUSLAVOVÁ R, ŠKODOVÁ Z, PIŤHA J, BOBKOVÁ D, POLEDNE R: Polymorphisms in the APOA1/C3/A4/A5 gene cluster and cholesterol responsiveness to dietary change. Clin Chem Lab Med 45: 316-320, 2007.

HUBÁČEK JA, ŠKODOVÁ Z, LÁNSKÁ V, ADÁMKOVÁ V: APOA5 variant (T-1131>C) affect plasma levels of non-HDL cholesterol in Caucasians. Exp Clin Cardiol 13; 129-132, 2008a.

HUBÁČEK JA, WANG W, ŠKODOVÁ Z, ADÁMKOVÁ V, VRABLÍK M, HOŘÍNEK A, ŠTULC T, ČEŠKA R, TALMUD PJ: APOA5 Ala315>Val, identified in patients with severe hypertriglyceridemia is a common mutation with no major effect on plasma lipid levels. Clin Chem Lab Med 46: 773-777, 2008b.

HUBÁČEK JA, LÁNSKÁ V, ŠKODOVÁ Z, ADÁMKOVÁ V, POLEDNE R: Sex-specific interaction between APOE and APOA5 variants and determination of plasma lipid levels. Eur J Hum Genet 16: 135-138, 2008c.

HUBÁČEK JA, ADÁMKOVÁ V, PRUSÍKOVÁ M, SNEJDRLOVÁ M, HIRSCHFELDOVÁ K, LÁNSKÁ V, ČEŠKA R, VRABLÍK M: Statin effect on lipid response according the apolipoprotein A5 variants. Pharmacogenomics 10: 945-950, 2009.

JANG Y, KIM JY, KIM OY, LEE JE, CHO H, ORDOVAS JM, LEE JH: The $-1131 \mathrm{~T} \rightarrow$ C polymorphism in the apolipoprotein A5 gene is associated with postprandial hypertriacylglycerolemia; elevated small, dense LDL concentrations; and oxidative stress in nonobese Korean men. Am J Clin Nutr 80: 832-840, 2004.

KADLECOVÁ M, HOJNÁ S, BOHUSLAVOVÁ R, HUBÁČEK JA, ZICHA J, KUNEŠ J: Apolipoprotein A5 and hypertriglyceridemia in Prague hypertriglyceridemic rats. Physiol Res 55: 373-379, 2006.

KAO JT, WEN HC, CHIEN KL, HSU HC, LIN SW: A novel genetic variant in the apolipoprotein A5 gene is associated with hypertriglyceridemia. Hum Mol Genet 12: 2533-2539, 2003.

MCNAMARA JR, SHAH PK, NAKAJIMA K, CUPPLES LA, WILSON PW, ORDOVAS JM, SCHAEFER EJ: Remnant-like particle (RLP) cholesterol is an independent cardiovascular disease risk factor in women: results from the Framingham Heart Study. Atherosclerosis 154: 229-236, 2001.

O'BRIEN PJ, ALBORN WE, SLOAN JH, ULMER M, BOODHOO A, KNIERMAN MD, SCHULTZE AE, KONRAD RJ: The novel apolipoprotein A5 is present in human serum, is associated with VLDL, HDL, and chylomicrons, and circulates at very low concentrations compared with other apolipoproteins. Clin Chem 51: 351-359, 2005.

PENNACCHIO LA, OLIVIER M, HUBÁČEK JA, COHEN JC, COX DR, FRUCHART JC, KRAUSS RM, RUBIN EM: An apolipoprotein influencing triglycerides in humans and mice revealed by comparative sequencing. Science 294: 169-173, 2001.

PENNACCHIO LA, OLIVIER M, HUBÁČEK JA, KRAUS RK, RUBIN EM, COHEN JC: Two independent apolipoprotein AV haplotypes influence human plasma triglyceride levels. Hum Mol Genet 11: 3031-3038, 2002.

PRIORE OLIVA CP, PISCIOTTA L, LI VOLTI G, SAMBATARO MP, CANTAFORA A, BELLOCCHIO A, CATAPANO A, TARUGI P, BERTOLINI S, CALANDRA S: Inherited apolipoprotein A-V deficiency in severe hypertriglyceridemia. Arterioscler Thromb Vasc Biol 25: 411-417, 2005.

RUSSO GT, MEIGS JB, CUPPLES LA, DEMISSIE S, OTVOS JD, WILSON PW, LAHOZ C, CUCINOTTA D, COUTURE P, MALLORY T, SCHAEFER EJ, ORDOVAS JM: Association of the Sst-I polymorphism at the APOC3 gene locus with variations in lipid levels, lipoprotein subclass profiles and coronary heart disease risk: the Framingham offspring study. Atherosclerosis 158: 173-181, 2001.

SCHAEFER JR, SATTLER AM, HACKLER B, KURT B, HACKLER R, MAISCH B, SOUFI M: Hyperlipidemia in patients with apolipoprotein E 2/2 phenotype: apolipoprotein A5 S19W as a cofactor. Clin Chem 50: 2214, 2004. 
SCHAAP FG, RENSEN PC, VOSHOL PJ, VRINS C, VAN DER VLIET HN, CHAMULEAU RA, HAVEKES LM, GROEN AK, VAN DIJK KW: ApoAV reduces plasma triglycerides by inhibiting very low density lipoproteintriglyceride (VLDL-TG) production and stimulating lipoprotein lipase-mediated VLDL-TG hydrolysis. $J$ Biol Chem 279: 27941-27947, 2004.

SUCHÁNEK P, LORENZOVÁ A, POLEDNE R, HUBÁČEK JA: Influence of apolipoprotein A5 polymorphism on lifestyle modification response in obese females. Ann Hum Nutr 53: 104-108, 2008.

TAI ES, ORDOVAS JM: Clinical significance of apolipoprotein A5. Curr Opin Lipidol 19: 349-354, 2008.

TALMUD PJ, HUMPHRIES SE. Genetic polymorphisms, lipoproteins and coronary artery disease risk. Curr Opin Lipidol 12: 405-409, 2001.

VRABLÍK M, HOŘÍNEK A, ČEŠKA R, ADÁMKOVÁ V, POLEDNE R, HUBÁČEK JA: Ser19 $\rightarrow$ Trp polymorphism within the apolipoprotein AV gene in hypertriglyceridemic people. $J$ Med Genet 40: e105, 2003.

VRÁNA A, KAZDOVÁ L: The hereditary hypertriglyceridemic nonobese rat: an experimental model of human hypertriglyceridemia. Transplant Proc 22: 2579, 1990.

WARD KJ, SHIELDS B, KNIGHT B, SALZMANN MB, HATTERSLEY AT, FRAYLING TM: Genetic variants in apolipoprotein AV alter triglyceride concentrations in pregnancy. Lipids Health Dis 2: 9, 2003. 